\section{CONCLUSIONS AND RECOMMENDATIONS}

We agree with the hypothesis that TP may be a structure similar to a lignotuber. But, because plants are grown in a nursery production environment with accelerated growth conditions, the lignotubers produced are abnormal and malformed in their morphology and unable to regrow. Additional research is needed to identify if other cultural factors may affect the occurrence of TP. Anatomical research will reflect any relationships between lignotuber and TP. Breeding studies should be conducted to examine the heritability of TP. These possibilities need to be further investigated to understand the nature of and possible triggers to the occurrence of TP.

\section{Literature Cited}

American Nurseryman. 1992. Temporary ill mars rhododendron crops. Amer. Nurseryman 175(3): 15-18.

Anderson, W.C. 1978. Rooting of tissue cultured rhododendrons. Intl. Plant Prop. Soc. 28:135-139.

Barrett, L.I. 1941. War revives an old industry. Amer. Forests 47:503-507

Brand, M.H. 1992. Tissue culture variations: Solutions. Amer. Nurseryman 175(5):66-71.

Brand, M.H. and R. Kiyomoto. 1992. Abnormal growths on micropropagated elepidote rhododendrons. Comb. Proc. Intl. Plant Prop. Soc. 42:530-534.

Brand, M.H. and R. Kiyomoto. 1994. Tissue proliferation apparently not lignotubers. Yankee Nursery Quarterly 3(4):5-6

Clark, E., H. Vigodsky-Haas, and Y. Gafni. 1989. Characteristics in tissue culture of hyperplasias induced by Erwinia herbicola pathovar gypsophilae. Physiol. Mol. Plant Pathol. 35:383-390.

Del Tredici, P. 1992. Seedling versus tissue-cultured Kalmia latifolia:The case of the missing burl. Comb. Proc. Intl. Plant Prop. Soc. 42:476-482.

Demaree, J.B. and N.R. Smith. 1952. Nocardia vaccinnii n. sp. causing galls on blueberry plants. Phytopathology 42:249-252.
Flinn, M.A. and R.W. Wein. 1977. Depth of underground plant organs and theoretical survival during fire. Can. J. Bot. 55:2550-2554.

Garland, H. and L. Marion. 1960. California manzanita for smoking pipes. Misc. Paper. Forest Serv.-U.S. Dept. of Agr. Pacific S.W. Forest and Range Expt. Sta. no. 53:1-12.

James, S. 1984. Lignotubers and burls: Their structure, function and ecological significance in Mediterranean ecosystems. Bot. Rev. 50:225-266.

Jones, J.B. 1979. Commercial use of tissue culture for the production of disease free plants. p. 441-452. In: Sharp et al. (eds.). Plant cell and tissue culture: Principles and applications. Ohio State Univ. Press, Columbus.

Kiyomoto, R.K. and M.H. Brand. 1994 Tissue proliferation in elepidote rhododendrons. HortScience 29:516.

LaMondia, J.A., T.M. Rathier, V.L. Smith, T.M. Likens, and M.H. Brand. 1992. Tissue proliferation/crown gall in rhododendron. Yankee Nursery Quarterly 2:1-3.

Linderman, R.G. 1993. Tissue proliferation. Amer. Nurseryman 178(5):57-67.

Maynard, B.K. 1995. Research update on tissue proliferation. Comb. Proc. Intl. Plant Prop. Soc. 45:442-447.

Moore, L.W. 1986. Diseases caused by bacteria, p. 29-30. In: D.L. Coyier and M.K. Roane (eds.). Compendium of rhododendron and azalea diseases. APS Press, St. Paul, Minn.

Peattie, D.C. 1950. A natural history of trees of eastern and central North America. The Riverside Press, Cambridge. p. 525-526.

Pogany, M.F. and R.D. Lineberger. 1990. Phenotypic variation during micropropagation of the chimeral Rhododendron 'President Roosevelt'. Plant Cell Tiss. Organ Cult. 21:201-209.

Rostan, Timothy. 1992. Phenomenon continues to defy answers. Amer. Nurseryman $176(1): 17,20$.

Salley, H.E. and H.E. Greer. 1992. Rhododendron hybrids. Timber Press, Portland, Ore.

Sinclair, W.A., H.H. Lyon, and W.T. Johnson. 1987. Diseases of trees and shrubs. Comstock Publishing Assoc., Ithaca, N.Y.

Smith, R.H. and A.E. Nightingale. 1979. In vitro propagation of Kalanchoe. HortScience 14:20.

\title{
The Induction of Tissue Proliferation-like Characteristics in In Vitro Cultures of Rhododendron 'Montego'
}

\author{
Mark H. Brand \\ Department of Plant Science, U-67, The University of Connecticut, Storrs, CT 06269-4067 \\ Richard Kiyomoto \\ Department of Forestry and Horticulture, The Connecticut Agricultural Experiment Station, New Haven, \\ CT 06504-1106
}

The term tissue proliferation(TP) was firstemployed by a workgroup of growers, research scientists and Oregon and Washington Dept. of Agriculture officials (Obermire and Milbrath, unpublished). TP is described as an abnormal callus-like growth produced at or near the crown of a plant (LaMondia et al., 1992). The tumors may or may not be accompanied by a proliferation of shoots and buds (Brand and Kiyomoto, 1992; Linderman, 1993). TP shoots are small, with short internodes and a whorled-leaf arrangement (Brand, 1992a). These shoots are short-lived, and die off regularly, only to be replaced by new shoots (Brand, 1992a).

TP has been reported in numerous locations in the continental United States and in Europe (LaMondia et al., 1992). Genera in which TP has been observed include Rhododendron, Kalmia, and Pieris (Linderman, 1993), but TP occurrence has been most problematic in Rhododendron. Various Rhododendron cultivars, mostly elepidotes, have been observed with TP symptoms (Brand and Kiyomoto, 1992; Linderman, 1993).

Received for publication 22 Aug. 1996. Accepted for publication 23 Dec. 1996. Storrs Agricultural Experiment Station scientific contribution no. 1656. This research was funded in part by funds made available through the Holden Arboretum, Mentor, Ohio. The cost of publishing this paper was defrayed in part by the payment of page charges. Under postal regulations, this paper therefore must be hereby marked advertisement solely to indicate this fact.
The occurrence of TP on Rhododendron was not reported until the widespread use of plants originating from tissue culture (Brand, 1992a). Although some growers report occasionally observing TP on seedling and cutting-propagated plants, the vast majority of plants developing TP have been micropropagated. The symptoms of TP become most noticeable on plants 2 to 5 years following propagation (LaMondia et al., 1992). Close inspection of young micropropagated plants reveals that TP tumors and symptoms are evident well before reaching mature nursery size. The effect TP has on plant health is unknown, and landscape performance of rhododendrons with TP has been questioned. Experimental evidence is required to determine the biological basis of TP to remedy its occurrence (Brand and Kiyomoto, 1992).

Because of the similarities between TP symptoms and crown gall, Agrobacterium involvement has been suspected as a possible cause for TP. Investigations searching for supportive evidence of Agrobacterium's role in TP have strongly indicated that TP is not caused by Agrobacterium tumefaciens (Linderman, 1993). Evidence for the involvement of other microbial agents or mycoplasma-like organisms in TP has not been found (Linderman, 1993). Additional evidence against a pathogenic cause for TP is supported by the observation that TP in rhododendrons does not appear to be highly contagious (American Nurseryman, 1992). Although TP does not appear to be pathogen-induced, this possibility still remains viable. 
Several genera in the Ericaceae, including Arctostaphylos, Kalmia, and Rhododendron, form natural lignotubers as survival structures against fire (Del Tredici, 1992). Lignotubers are swollen, woody structures containing dormant buds, found at the crown of some woody plants (James, 1984). Linderman (1993) has theorized that TP in Rhododendron is the expression of naturally occurring lignotubers, which may be enhanced or triggered by passage through tissue culture. However, experiments in which tops were removed from rhododendrons with TP showed no vegetative regrowth that could be unambiguously linked to buds produced on the proliferations (Brand and Kiyomoto, 1994b), which suggests that TPs are not the functional equivalent of lignotubers.

The theory that TP results from epigenetic changes brought about by the tissue culture process has received the greatest support from those familiar with the condition (Linderman, 1993). Epigenetic variation is also known as developmental variation (Skirvin et al., 1994). It includes persistent changes in phenotype that involve the expression of particular genes (Hartmann and Kester, 1983).

One of the best known epigenetic changes is phase change in woody perennials (Poethig, 1990). It has been demonstrated that tissue culture can cause a form of rejuvenation or reinvigoration in woody plants (Brand and Lineberger, 1992a, 1992b; Marks, 1991a; Webster and Jones, 1989). In vitro rejuvenation, therefore, is an example of tissue culture induction of epigenetic changes and an altered phenotype. Another well-known example of epigenetic variation triggered by tissue culture is the loss of auxin, cytokinin, or vitamin requirements by callus (Jackson and Lyndon, 1990; Meins, 1989; Skirvin, 1978). These changes in requirements are collectively known as tissue or cellular habituation.

This paper documents differences in the behavior of shoot cultures initiated from Rhododendron plants with and without TP. Evidence is also provided confirming that tissue culture can convert Rhododendron tissue free of TP to a condition of altered behavior and morphology analogous to tissue with TP.

\section{EXPERIMENTS CONDUCTED}

Plant materials. Rhododendron 'Montego' was used in all studies because preliminary work indicated it developed TP morphology that would make it a model system for studying the phenomenon (Brand and Kiyomoto, 1994a). Cuttings collected from the original seedpropagated 'Montego' plant were received from David Leach of the Holden Arboretum, Mentor, Ohio, in Nov. 1992. Cuttings were rooted and the resulting plants provided tissue and explants referred to as $\mathrm{TP}(-)$ and were free of TP.

Rhododendron 'Montego' plants exhibiting TP symptoms were obtained from a commercial nursery in March 1993. These plants had been micropropagated and provided tissue and explants referred to as $\mathrm{TP}(+)$. All TP(+) and TP(-) plants were maintained in an outdoor container growing area and overwintered in unheated plastic-covered hoop houses. During the spring, plants were moved to a greenhouse to force shoots that could be used to initiate tissue cultures. Plants were maintained in plastic pots filled with 3 pine : 2 peatmoss: 1 sand (by volume) mix supplemented with $\left(\mathrm{kg} \cdot \mathrm{m}^{-3}\right) 1.3$ each of ground dolomitic limestone and gypsum. Annual $\mathrm{N}-\mathrm{P}-\mathrm{K}$ and micronutrient needs were supplied with $17 \mathrm{~N}-2.6 \mathrm{P}-3.8 \mathrm{~K}$ controlled-release fertilizer(Sierrablen; Grace-Sierra, Milpitas, Calif.). No herbicides and other pesticides were applied to the plants to avoid any effects those materials might have had on plant growth and development.

Culture initiation and maintenance. Recently expanded shoots were collected from $\mathrm{TP}(+)$ and $\mathrm{TP}(-)$ plants separately, using ethanolsterilized knives. Shoots were stripped of leaves, trimmed to $4 \mathrm{~cm}$, washed in soapy water, rinsed under running tap water for $5 \mathrm{~min}$, and explants were disinfested in agitated $10 \%$ commercial bleach (sodium hypochlorite $5.25 \%$ ) and five drops of Tween 20 per $500 \mathrm{~mL}$, for 12 min. Following three rinses in sterile distilled water, disinfested shoots were trimmed at the base to $2 \mathrm{~cm}$ before placement on culture medium in individual vessels. Woody plant (WP) medium (Lloyd and McCown, 1980) (pH 5.2 prior to autoclaving), containing 3\% sucrose, $0.3 \%$ agar (Sigma Chemical Co., St. Louis) and $0.1 \%$ Phytagel (Sigma Chemical Co.), was the basal medium used for all studies. To initiate $\mathrm{TP}(+)$ and
$\mathrm{TP}(-)$ cultures, basal medium was supplemented with $10 \mu \mathrm{M} 6-(\gamma, \gamma-$ dimethylallylamine) purine (2iP). TP(-) cultures were maintained continuously thereafter on WP medium containing $10 \mu \mathrm{M} 2 \mathrm{iP}$. At transfer, basal callus and other tissue that appeared adventitious in origin were trimmed away and discarded. Only elongated, wellexpanded, large shoots were carried forward at transfer. Apical and nodal pieces ( 1 to $2 \mathrm{~cm}$ long) were used to perpetuate the cultures by axillary release at a relatively slow multiplication rate.

Following the onset of shoot size reduction and rapid proliferation, $\mathrm{TP}(+)$ cultures were maintained on basal medium without $2 \mathrm{iP}$. The dwarf, compact nature of the shoot systems that developed required the subculture of small shoot clusters, rather than individual shoots. All cultures in all in vitro studies were transferred to fresh medium every 5 weeks.

During initiation, cultures were grown for the initial two subculture periods in $25 \times 150$-mm culture tubes, sealed with clear polypropylene caps. Cultures were thereafter maintained in 200 -mL glass jars, sealed with B-caps (Magenta Corp., Chicago). Six explants were transferred to each jar at subculture. Culture tubes contained $15 \mathrm{~mL}$ of medium and jars contained $30 \mathrm{~mL}$. The environment for all in vitro cultures in all studies was $24 \pm 2{ }^{\circ} \mathrm{C}$ and $16 \mathrm{~h} \cdot \mathrm{d}^{-1}$ of coolwhite light $\left(40 \mu \mathrm{mol} \cdot \mathrm{m}^{-2} \cdot \mathrm{s}^{-1}\right)$. As of July 1995 , cultures had been maintained for 28 months. Shoot tip cultures were initiated in April 1993 and again in April 1994 to replicate the study.

Once cultures were established and multiplying steadily, TP(+) and TP(-) shoots were placed on the following media: 1) WP basal medium; 2) WP basal medium containing $0.06 \%$ activated charcoal (Sigma Chemical Co.), and 3) WP basal medium containing $10 \mu \mathrm{M} 2 \mathrm{iP}$. Individual shoot tips (10 mm long) were selected from TP(-) cultures and maintained on medium containing $10 \mu \mathrm{m} 2 \mathrm{iP}$, while small, 3-5 branched shoot clusters (10 mm long) were selected from TP $(+)$ cultures maintained on basal medium. Explants were maintained in previously described culture tubes for the first two subculture periods and in previously described jars for two additional subculture periods (20 weeks). A completely randomized design was used.

Induction of TP-like characteristics in TP(-) cultures. Attempts to induce TP-like in vitro morphology and growth in TP(-) shoot cultures focused on adventitious shoot formation on leaves and $2 \mathrm{iP}$ concentrations supplied to shoot cultures. Fifty leaves collected from TP(-) shoot cultures were placed abaxial side down on medium, five per vessel. Transfers to fresh medium were made at 5-week intervals. For the initial 10 weeks, leaves were cultured in $100 \mathrm{~mm} \times 15 \mathrm{~mm}$ petri dishes containing $30 \mathrm{~mL}$ of WP medium, supplemented with $1 \mu \mathrm{M}$ indole-3-butyric acid (IBA) and $30 \mu \mathrm{M} 2 \mathrm{iP}$. For the next 5 weeks, cultures were grown on WP basal medium to encourage shoot expansion and enhance visualization of TP-like characteristics. After 15 weeks, shoots regenerated on the leaves were segregated into those with $\mathrm{TP}(-)$ in vitro characteristics [putative $\mathrm{TP}(-)$ ] and those with $\mathrm{TP}(+)$ in vitro characteristics [putative $\mathrm{TP}(+)$ ]. Putative $\mathrm{TP}(-)$ shoots were placed in previously described glass jars, on WP medium supplemented with $10 \mu \mathrm{m} 2 \mathrm{iP}$. Putative TP(+) shoots were placed on basal WP medium. After 10 weeks (two subcultures), shoots were harvested for rooting. At the same time, TP(+) and TP(-) microcuttings were harvested from maintenance cultures. Remaining putative $\mathrm{TP}(+)$ and $\mathrm{TP}(-)$ cultures were evaluated for growth response on growth regulator-free and $10 \mu \mathrm{M} 2 \mathrm{iP}$ media.

Microcuttings were rooted under nonsterile conditions in a moistened 3 screened sphagnum moss : 1 vermiculite $(v / v)$ mix in $20 \times 15$ $\times 8$-cm clear plastic trays at a density of 40 microcuttings per tray. Environmental conditions were as described previously for culture maintenance. Rooting was evaluated after 8 weeks. Rooted microcuttings were acclimated to greenhouse conditions by gradually increasing light and reducing humidity (Brand and Lineberger, 1986). In the greenhouse $\left(16^{\circ} \mathrm{C}\right.$ night $/ 27^{\circ} \mathrm{C}$ day $)$, plants were grown in $10.2 \times 10.2$ $\mathrm{cm}$ square plastic pots in the previously described potting medium. A 16-h light/24-h day photoperiod was provided by sodium high-intensity discharge lamps. Following 4 months in the greenhouse, plants were repotted into 3.8-L containers and moved to an outdoor growing area with trickle irrigation. Plants were evaluated 7 months postacclimation for shoot and leaf morphological characteristics. Leaf measurements were taken on the first five fully expanded apical leaves 
on an individual growth flush. Leaf length was measured from the tip of the blade to the blade base. Leaf width was measured at the widest part of the blade. Leaf area was obtained using an LI 3100 leaf area meter (LI-COR, Lincoln, Nebr.). Shoot length was measured from the bud scale scars to the base of the apical bud. The distance from the bud scale scars to the first leaf was recorded as the basal shoot length. Morphological measurements were also taken for $\mathrm{TP}(+)$ and $\mathrm{TP}(-)$ stock plants from which tissue cultures were initiated. A completely randomized design was used for this study. Data were tested using analysis of variance (ANOVA) and correlation analysis (SAS Institute, 1990).

In a second study, TP(-) shoot tips ( $10 \mathrm{~mm}$ long) from maintenance cultures were placed on WP medium with either 10 or $50 \mu \mathrm{M} 2 \mathrm{iP}$. Individual shoots were placed in culture tubes containing $15 \mathrm{~mL}$ of medium, as previously described, for the first culture period. For two subsequent subculture periods, individual cultures were placed in previously described glass jars with $30 \mathrm{~mL}$ of medium. During the third subculture period, shoot clusters were removed to basal medium to encourage shoot extension and expression of TP-like characteristics. Cultures were not cut or otherwise subdivided during the study.

During the first and second transfer, the amount of apparent adventitious meristem formation was rated based on the width $(\mathrm{mm})$ of the basal meristem mass that formed on many shoots: $0=$ none; 1 $=0-2 ; 2=2.1-4 ; 3=4.1-8 ; 4=8.1-12 ; 5=\geq 12.1$. At the end of the third subculture period, cultures were checked for the presence of tumors and dwarf, compact, multibranched shoot clumps that were capable of growth regulator-autonomous growth. A completely randomized design was used for this study. Data were tested using ANOVA and correlation analysis (SAS Institute, 1990).

\section{FINDINGS}

Culture initiation and maintenance. Shoot tips collected from $\mathrm{TP}(+)$ and TP(-) 'Montego' plants behaved differently during the culture initiation period. During the first 2 months following placement on initiation medium, both types of shoot tips initiated growth from the apex and some lateral buds, but shoot size reduction and adaptation to in vitro conditions, leading to rapid shoot proliferation, did not occur. Between 2 and 4 months postinitiation (PI), cultures began to diverge in their response to in vitro conditions. In TP(+) cultures, shoots became much smaller and the rate of shoot multiplication began to increase. During the same time period, $\mathrm{TP}(-)$ shoots continued slow extension of the original shoot apex with minimal reduction in shoot size and no increase in the rate of shoot multiplication.

By 6 months PI, TP(+) cultures had entered a condition of excessive shoot multiplication, where shoots branched at nearly every node and shoot elongation was minimal. In addition, tumors or swellings developed on TP $(+)$ shoots. These tumors formed at the nodes and appeared to develop following the initiation of growth of the axillary shoot. At the onset of tumor development, the axillary shoot ceased or slowed extension. Tumors eventually grew to several millimeters in diameter. Initially, tumors possessed a smooth surface and intact epidermis, but, as they aged and grew larger, often formed eruptions that appeared similar to typical growth of callus on solid culture medium. Tumors formed what appeared to be adventitious roots, but such formations usually occurred only on cultures beyond the 5-week subculture period. More commonly, shoot meristems or leafy structures appeared on the surface of tumors. We do not know whether these structures are adventitious in nature, or originate from the initial axillary meristem at the node.
Reduction in shoot size and initiation of multiplication of TP(-) shoots did not occur until 10 months PI. At this time, TP(+) cultures had to be switched from medium containing $10 \mu \mathrm{M} 2 \mathrm{iP}$ to basal medium. Under the influence of continual exposure to $2 \mathrm{iP}$, shoot extension became so limited that cultures consisted of clusters of tumors and meristems, with no shoot development. Slow but steady multiplication and in vitro adaptation of TP(-) cultures did not occur until 14 months PI. Table 1 summarizes the development of TP $(+)$ and $\mathrm{TP}(-)$ shoot cultures during a 14-month culture initiation period.

In vitro-adapted TP( + ) cultures were maintained for 18 months on basal medium. During this period, shoot multiplication was maintained at a steady and rapid rate. Cultures continued to develop tumors and shoot extension remained limited (Fig. 1A). When placed back on $10 \mu \mathrm{M} 2 \mathrm{iP}$ medium for 20 weeks, $\mathrm{TP}(+)$ shoots rapidly returned to compact masses of tumors and meristems, with minimal shoot extension (Fig. 1B). Moving TP(+) shoots from basal medium to charcoalcontaining medium had little effect on plant growth (Fig. 1C). Shoot elongation did not improve to a noticeable level.

$\mathrm{TP}(-)$ cultures maintained on $10 \mu \mathrm{M} 2 \mathrm{iP}$ medium for 28 months did not increase shoot multiplication above that observed at 14 months PI. Shoots elongated well, but multiplied slowly (Fig. 1D). TP(-) cultures did not form tumors under the management conditions described. Basal or charcoal-containing media induced TP(-) shoots to root and inhibited shoot multiplication.

Induction of TP-like characteristics in TP(-) cultures. Shoot organogenesis occurred on $82 \%$ of leaves. The majority of leaves produced shoot clusters that elongated normally and required exogenous $2 \mathrm{iP}$ to maintain shoot multiplication [putative TP(-)] (Fig. 2A). Out of 41 leaves producing adventitious shoots, six leaves (15\%) produced in vitro growth resembling that observed for cultures initiated from $\mathrm{TP}+$ plants [putative $\mathrm{TP}(+)$ ]. Individual cultures would often produce sectors of normal shoots adjacent to dwarf, tumorous sectors (Fig. 2B). Gradations in the level of dwarfness were also observed between different tumorigenic clusters (Fig. 2C). These shoot clusters proliferated dwarf shoots freely on basal medium, and numerous tumors were present on the cultures. To date, dwarf shoots have been maintained on basal medium for 14 months without a reduction in shoot multiplication. Throughout the 14 months, numerous tumors existed on cultures.

Rooting was similar for putative $\mathrm{TP}(+)$, putative $\mathrm{TP}(-), \mathrm{TP}(+)$ and $\mathrm{TP}(-)$ microcuttings, although putative $\mathrm{TP}(+)$ and $\mathrm{TP}(+)$ plantlets appeared to be less vigorous than putative $\mathrm{TP}(-)$ and $\mathrm{TP}(-)$ plantlets. When microcuttings were evaluated at 7 months postacclimation, significant differences in leaf and shoot morphology existed (Tables 2 , $3)$. Plants from TP(-) cultures had the longest, widest, and largest leaves, and the lowest leaf length: width ratio(Table 2, Fig. 3A). TP(+) plants had short, narrow leaves, the smallest leaf area, and the highest leaf length : width ratio (Fig. 3B). Shoots of TP(-) plants were significantly longer than $\mathrm{TP}(+)$ shoots.

Putative TP(+) plants from adventitious origin were statistically similar to $\mathrm{TP}(+)$ plants in all measured leaf and stem characteristics. Leaves on putative TP(-) plants of adventitious origin were intermediate between TP(+) and TP( $(-)$ leaves for leaf length, width, area, and length : width ratio. Putative TP(-) shoots were statistically similar to TP(-) shoots. Plants of all origins had the same number of leaves per growth flush.

Leaves of all TP(-) plants (80) and putative TP(-) plants (40) developed red adaxial petiole surfaces. Leaves of all TP(+) plants $(80)$ and putative $\mathrm{TP}(+)$ plants $(40)$ had green petioles. None of the plants produced visible tumors during the 7-month postacclimation period.

$\mathrm{TP}(-)$ shoot tips grown on medium containing 10 or $50 \mu \mathrm{M} 2 \mathrm{iP}$ exhibited differences in the amount of adventitious meristem forma-

Table 1. Timeline for behavior of Rhododendron 'Montego' shoot tip cultures initiated from TP(+) and TP(-) stock plants during the initiation period. Cultures were initiated on medium containing $10 \mu \mathrm{m} 2 \mathrm{iP}$.

\begin{tabular}{lll}
\hline \hline $\begin{array}{l}\text { Time since initiation of cultures } \\
\text { (months) }\end{array}$ & \multicolumn{1}{c}{ Behavior of Rhododendron } \\
\cline { 2 - 3 } & \multicolumn{1}{c}{ TP(-) } & \multicolumn{1}{c}{ TP $(+)$} \\
4 & Large shoot & Large shoot \\
6 & Large shoot & Shoot size reduced, initiation of multiplication \\
10 & Large shoot & Excessive multiplication, tumor formation \\
14 & Shoot size reduction, initiation of multiplication & Requires plant growth regulator-free medium \\
& Steady, slow multiplication; requires 2iP & Requires plant growth regulator-free medium \\
\hline
\end{tabular}

HortSCIENCE, Vol. 32(6), OCTOBER 1997 
tion (Table 4). More cultures grown on $50 \mu \mathrm{M} 2 \mathrm{iP}$ produced adventitious meristems (100\%) than cultures grown on $10 \mu \mathrm{M} 2 \mathrm{iP}(83 \%)$. In addition, $50 \mu \mathrm{M} 2 \mathrm{iP}$ cultures produced larger clumps of basal meristems that appeared to be adventitious in origin. Dwarf shoots with tumors grew in cultures with both 10 or $50 \mu \mathrm{M} 2 \mathrm{iP}$. However, $50 \mu \mathrm{M} 2 \mathrm{iP}$ produced tumorigenic dwarf shoots in $50 \%$ of the cultures, in comparison to only $10 \%$ of cultures with $10 \mu \mathrm{M} 2 \mathrm{iP}$ (Table 4 ).

\section{INTERPRETATION}

Rhododendron 'Montego' may represent a model system for studying TP in Rhododendron because of the morphological and physiological markers that are evident on plants with TP. 'Montego' shoot cultures produce clearly recognizable tumorous growths at nodes and also have altered growth regulator requirements. These tumorous growths and altered in vitro behavior are useful tools for identifying tissues that are $\mathrm{TP}(+)$ or have become $\mathrm{TP}(+)$ as the result of in vitro treatments or events. In vitro tumors have not been commonly observed on 18 other Rhododendron cultivars grown in vitro by us. Tumors similar to those on 'Montego' occur on $R$. 'Besse Howells', but at very low frequencies.

Intact, greenhouse-grown, or outdoor-grown TP(+) 'Montego' plants also exhibit altered leaf and shoot morphology that can be used to identify whether plants are $\mathrm{TP}(+)$ before distinct tumorous growths appear. A method of screening plants to determine TP status prior to development of basal and stem tumors can dramatically reduce the duration of studies on this phenomenon.

Following initiation, TP(+) shoot tip cultures are capable of shoot multiplication on basal medium indefinitely, and appear to be habituated. Habituation has been defined as callus proliferation in vitro in the absence of exogenous plant growth regulators in the nutrient medium (Gaspar et al., 1991; Meins, 1989). Although habituation is generally associated with callus behavior, shoot tip cultures may become growth regulator-independent in the same way normal growth regulatordependent calli become habituated (Gaspar et al., 1991; Pierik, 1989). Jackson and Lyndon (1990) suggest that some developmental processes in intact plants, such as autocatalytic ethylene synthesis, phase change, and leaf initiation, seem to imply involvement of habituationlike processes.

Habituated tissues may either produce excessive levels of endogenous growth hormones (Kerbauy et al., 1986), possess a reduced capacity to degrade growth hormones (Syono, 1979), or exhibit elevated sensitivity to growth hormones. Tumors may be localized areas of hormone overproduction, increased hormone sensitivity, or reduced hormone catabolism that is associated with axillary meristems at each node. Elevated cytokinin levels within tumorous areas may supply cytokinins to the entire shoot, leading to excessive shoot proliferation of TP $(+)$ cultures, even on basal media or media containing activated charcoal.

In some cases, it has been demonstrated that habituation has an epigenetic basis (Meins and Binns, 1977), and distinguishing between habituation and epigenetic change is often difficult. In vitro rejuvenation and reinvigoration, a documented tissue culture phenomenon (Brand and Lineberger, 1990a, 1990b; Webster and Jones, 1989) and a known epigenetic change (Hartmann and Kester, 1983), may represent a form of habituation (Jackson and Lyndon, 1990). Marks (1991a, 1991b) has demonstrated, based on ease of rooting and morphology, that the epigenetic change of rejuvenation occurs in rhododendron during tissue culture.

Our work demonstrates that TP can be induced in $R$. 'Montego' during in vitro culture. It appears that for $\mathrm{TP}(-)$ shoot cultures to develop TP(+) tissue, an adventitious event must occur. TP(+) tissues have not been observed to arise from axillary shoot multiplication. Although adventitious events have been shown to cause chimeral dissociation (Marcotrigiano, 1990), it remains unclear how adventitious shoot formation contributes to other types of tissue culture

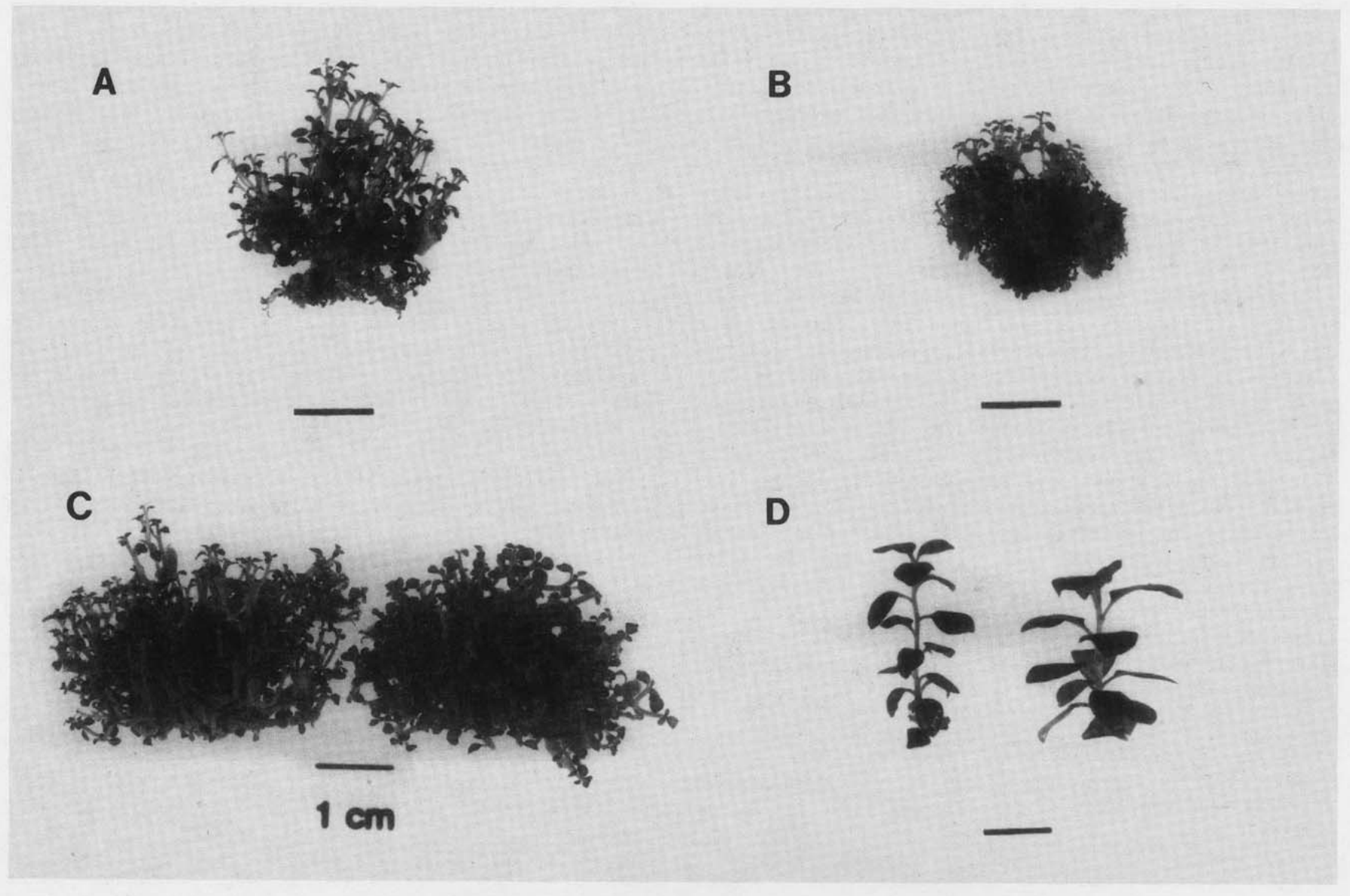

Fig. 1. Rhododendron 'Montego' shoot tip cultures on woody plant medium. $(\mathbf{A}) \mathrm{TP}(+)$ culture maintained on basal medium. (B) TP $(+)$ culture maintained on 10 $\mu \mathrm{M} 2 \mathrm{iP}$ medium. (C) $\mathrm{TP}(+)$ culture maintained on medium containing $0.06 \%$ activated charcoal. (D) TP(-) culture maintained on $10 \mu \mathrm{M} 2 \mathrm{iP}$ medium. 


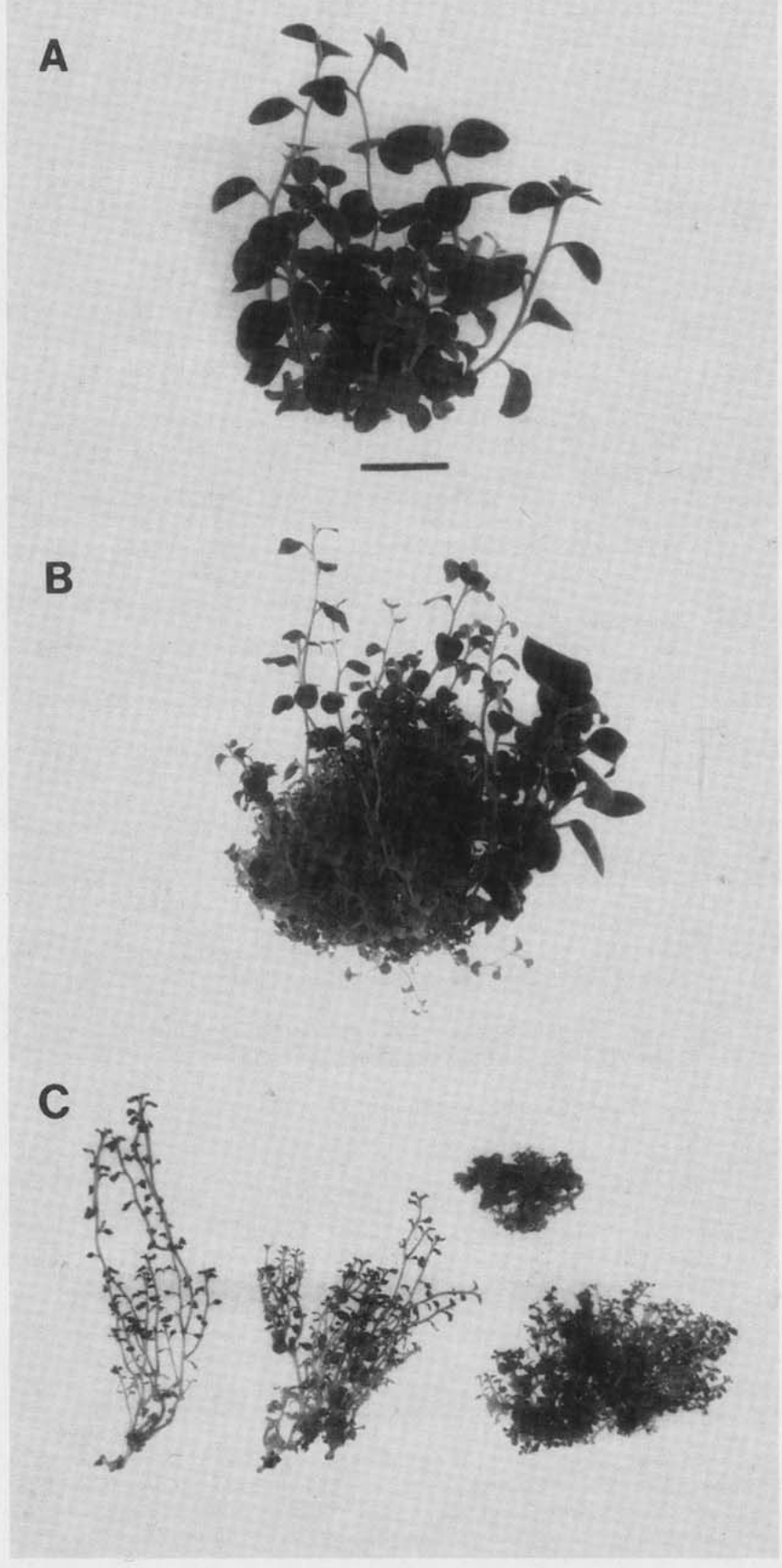

Fig. 2. Rhododendron 'Montego' shoot organogenesis from TP(-) leaves. (A) Putative TP(-) adventitiously regenerated shoots on woody plant medium containing $10 \mu \mathrm{M} 2 \mathrm{iP}$. (B) Shoot organogenesis on a TP(-) leaf showing development of putative TP(+) morphology (left) and some TP morphology (extreme right). (C) Various levels of dwarfness exhibited by the population of putative $\mathrm{TP}(+)$ adventitious regenerants. variation. Nonetheless, it is generally agreed that clonal stability is best achieved by avoiding adventitious shoot formation (Brand, 1992b; Karp, 1989; Skirvin, 1978). In $R$. 'Montego', all adventitious events, and likely most events, do not lead to complete conversion from a $\mathrm{TP}(-)$ phenotype to a $\mathrm{TP}(+)$ phenotype. Numerous adventitious shoots failed to produce in vitro tumors, required exogenous $2 \mathrm{iP}$ to multiply and grow, and exhibited in vitro morphology similar to cultures initiated from TP( $(-)$ plants. Intact plants produced from these shoots, although visually indistinguishable from $\mathrm{TP}(-)$ plants, were statistically intermediate between $\mathrm{TP}(+)$ and $\mathrm{TP}(-)$ plants for all leaf morphological data collected. These data may indicate that partial conversion from TP(-) to TP(+) may occur in many or all adventitious events. Further evidence in support of this idea comes from the variability in shoot dwarfness and tumorization in the population of adventitious regenerants categorized as putative $\mathrm{TP}(+)$.

Growth regulators, such as 2,4-dichlorophenoxyacetic acid $(2,4$ D) and $\mathrm{N}^{6}$-benzyladenine (BA), have been implicated in the induction of variability (Evans, 1988; Griesbach et al., 1988; Shoemaker et al., 1991), but their direct relationship to the phenomenon of tissue proliferation has not been conclusively proven. In this study, high $2 \mathrm{iP}$ concentration increased the incidence of adventitious shoot formation, which was correlated with the incidence of putative $\mathrm{TP}(+)$ shoot clusters. Other researchers have also demonstrated that elevated cytokinin concentration increases adventitious shoot formation in rhododendron (Ettinger and Preece, 1985; McCown and Lloyd, 1983). However, Keith and Brand (1995) found that $2 \mathrm{iP}$ concentration in vitro did not influence the amount of brooming observed in micropropagated lepidote rhododendrons.

Skirvin et al. (1994) state that expected somaclonal variation is probably about $1 \%$ to $3 \%$. The development of $\mathrm{TP}(+)$ phenotypes in $\mathrm{TP}(-)$ cultures was at rates far in excess of $3 \%$. In addition, all occurrences of variation resulted in the same or similar phenotype, that of $\mathrm{TP}(+)$ cultures and plants. It seems unlikely that the change from $\mathrm{TP}(-)$ phenotype to TP $(+)$ phenotype could be caused by mutation, since the rate of variation would be expected to be lower and the types of variation more diverse.

Many growers, concerned that tissue culture cannot produce plants free of TP, have refused to use micropropagated rhododendron in their production. Our work indicates that phenotypically normal rhododendron can be produced via micropropagation, and that stable, "normal" cultures can be easily maintained by vigilant removal of basal callus and adventitious meristem masses, use of low cytokinin levels to maintain slow-to-moderate shoot multiplication, and production of shoots exclusively through axillary multiplication.

\section{Literature Cited}

American Nurseryman. 1992. Temporary ill mars rhododendron crops. Amer. Nurseryman 176:15-18.

Brand, M.H. 1992a. Tissue culture variations: Problems. Amer. Nurseryman 175:60-65. Brand, M.H. 1992b. Tissue culture variations: Solutions. Amer. Nurseryman 175:66-71. Brand, M.H. and R. Kiyomoto. 1992. Abnormal growths on micropropagated elepidote rhododendrons. Proc. Intl. Plant Prop. Soc. 42:530-534.

Brand, M.H. and R. Kiyomoto. 1994a. Behavior of rhododendron tissue affected by tissue proliferation. In Vitro Cell. Dev. Biol. 30A:72 (Abstr.)

Brand, M.H. and R. Kiyomoto. 1994b. Tissue proliferation apparently not lignotubers. Yankee Nursery Quarterly 3:5-6.

Brand, M.H. and R.D. Lineberger. 1986. In vitro propagation of Halesia carolina L. and

Table 2. Leaf and shoot measurements of Rhododendron 'Montego' plants generated from TP(+) and TP(-) shoot cultures and from adventitiously generated putative $\mathrm{TP}(+)$ and $\mathrm{TP}(-)$ cultures.

\begin{tabular}{|c|c|c|c|c|c|c|c|}
\hline \multirow[b]{3}{*}{ Tissue type } & \multicolumn{7}{|c|}{ Plant characteristic } \\
\hline & \multicolumn{4}{|c|}{ Leaf } & \multicolumn{2}{|c|}{ Shoot length } & \multirow[b]{2}{*}{$\begin{array}{c}\text { Leaves/flush } \\
\text { (no.) }\end{array}$} \\
\hline & $\begin{array}{l}\text { Length }^{2} \\
(\mathrm{~cm})\end{array}$ & $\begin{array}{l}\text { Width } \\
(\mathrm{cm})\end{array}$ & $\begin{array}{l}\text { Area } \\
\left(\mathrm{cm}^{2}\right)\end{array}$ & $\begin{array}{l}\text { Length/width } \\
(\mathrm{cm})\end{array}$ & $\begin{array}{l}\text { Total }^{y} \\
(\mathrm{~cm})\end{array}$ & $\begin{array}{c}\text { Basal }^{\mathrm{x}} \\
(\mathrm{cm})\end{array}$ & \\
\hline $\mathrm{TP}(-)$ & $14.3 \mathrm{a}^{\mathrm{w}}$ & $4.5 \mathrm{a}$ & $49.4 \mathrm{a}$ & $3.2 \mathrm{c}$ & $8.1 \mathrm{a}$ & $4.5 \mathrm{a}$ & $12.2 \mathrm{a}$ \\
\hline $\mathrm{TP}(+)$ & $11.9 \mathrm{c}$ & $3.0 \mathrm{c}$ & $27.6 \mathrm{c}$ & $4.9 \mathrm{a}$ & $4.0 \mathrm{~b}$ & $2.1 \mathrm{~b}$ & $12.0 \mathrm{a}$ \\
\hline Putative TP( $(-)$ & $12.9 \mathrm{~b}$ & $3.8 \mathrm{~b}$ & $41.3 \mathrm{~b}$ & $3.4 \mathrm{~b}$ & $7.9 \mathrm{a}$ & $4.4 \mathrm{a}$ & $12.3 \mathrm{a}$ \\
\hline Putative TP(+) & $12.1 \mathrm{c}$ & $3.1 \mathrm{c}$ & $30.7 \mathrm{c}$ & $3.9 \mathrm{a}$ & $4.3 \mathrm{~b}$ & $2.2 \mathrm{~b}$ & $12.2 \mathrm{a}$ \\
\hline
\end{tabular}

${ }^{2}$ For leaf measurements, $\mathrm{n}=100$.

' For stem measurements, $\mathrm{n}=20$.

'Basal shoot length was measured from the bud scale scar to the first leaf petiole juncture.

"Mean separation within columns by Tukey's HSD test at $P \leq 0.05$. 


\section{WORKSHOP}

Table 3. Leaf and shoot measurement of TP(+) and TP(-) Rhododendron 'Montego' stock plants used as explant sources for culture initiation.

\begin{tabular}{|c|c|c|c|c|c|c|c|}
\hline \multirow[b]{3}{*}{ Tissue type } & \multicolumn{7}{|c|}{ Plant characteristic } \\
\hline & \multicolumn{4}{|c|}{ Leaf } & \multicolumn{2}{|c|}{ Shoot length } & \multirow[b]{2}{*}{ Leaves/flush } \\
\hline & $\begin{array}{l}\text { Length }^{2} \\
(\mathrm{~cm})\end{array}$ & $\begin{array}{l}\text { Width } \\
(\mathrm{cm})\end{array}$ & $\begin{array}{l}\text { Area } \\
\left(\mathrm{cm}^{2}\right)\end{array}$ & $\begin{array}{l}\text { Length/width } \\
(\mathrm{cm})\end{array}$ & $\begin{array}{l}\text { Total }{ }^{y} \\
(\mathrm{~cm})\end{array}$ & $\begin{array}{l}\text { Basal }^{x} \\
\text { (no.) }\end{array}$ & \\
\hline $\mathrm{TP}(-)$ & $10.0 \mathrm{a}^{\mathrm{w}}$ & $3.5 \mathrm{a}$ & $25.8 \mathrm{a}$ & $2.9 \mathrm{~b}$ & $7.7 \mathrm{a}$ & $4.3 \mathrm{a}$ & $10.9 \mathrm{a}$ \\
\hline $\mathrm{TP}(+)$ & $8.3 \mathrm{~b}$ & $2.4 \mathrm{~b}$ & $14.3 \mathrm{~b}$ & $3.5 \mathrm{a}$ & $3.8 \mathrm{~b}$ & $1.9 \mathrm{~b}$ & $10.2 \mathrm{a}$ \\
\hline
\end{tabular}

${ }^{\mathrm{x}}$ For leaf measurements, $\mathrm{n}=75$.

${ }^{\mathrm{y}}$ For stem measurements, $\mathrm{n}=15$.

${ }^{x}$ Basal shoot length was measured from the bud scale scar to the first leaf petiole juncture.

"Mean separation within columns by Tukey's HSD test at $P \leq 0.05$.

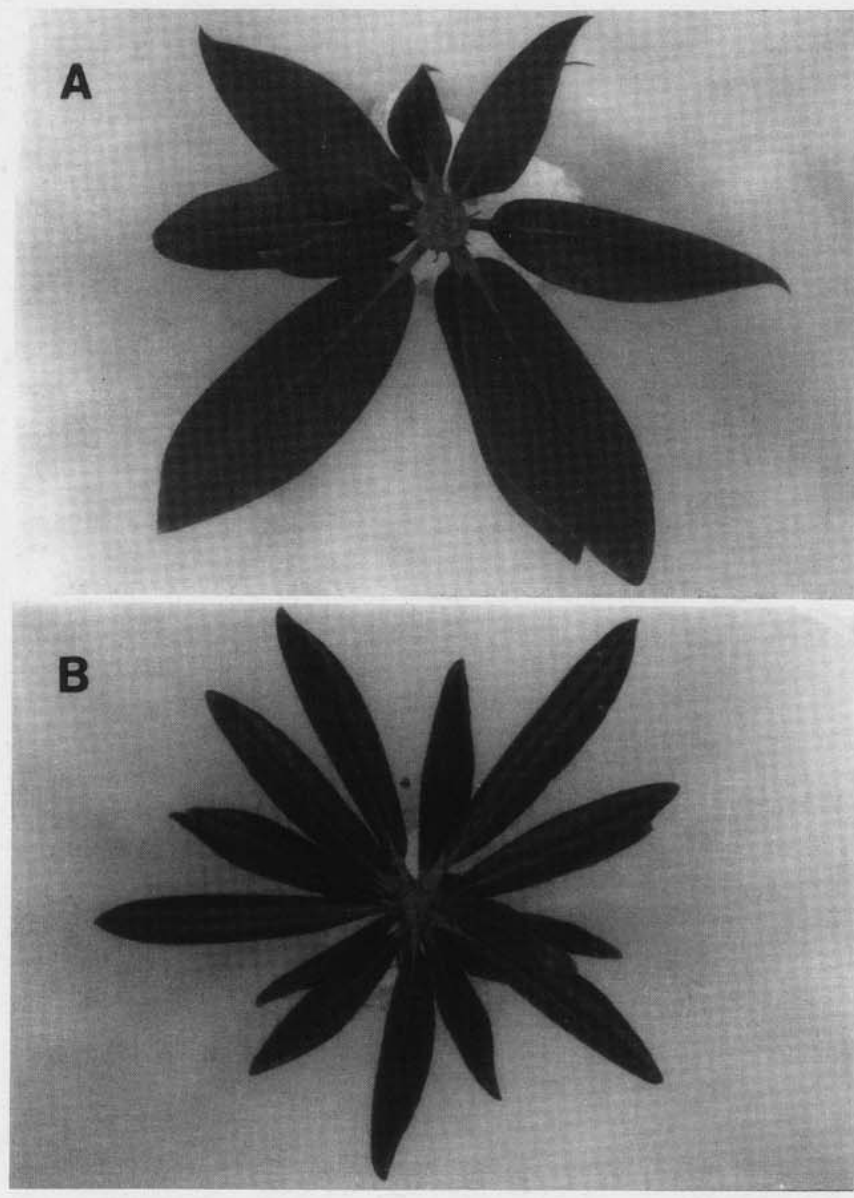

Fig. 3. Rhododendron 'Montego' shoots from micropropagated plants. (A) $\mathrm{TP}(-)$ shoot. (B) $\mathrm{TP}(+)$ shoot.

the influence of explantation timing on initial shoot proliferation. Plant Cell Tissue Organ Cult. 7:103-113.

Brand, M.H. and R.D. Lineberger. 1992a. In vitro rejuvenation of Betula (Betulaceae): Morphological evaluation. Amer. J. Bot. 618-625.

Brand, M.H. and R.D. Lineberger. 1992b. In vitro rejuvenation of Betula (Betulaceae) Biochemical evaluation. Amer. J. Bot. 626-635.

Del Tredici, P. 1992. Seedling versus tissue-cultured Kalmia latifolia: The case of the missing burl. Proc. Intl. Plant Prop. Soc. 42:476-482.

Ettinger, T.L. and J.E. Preece. 1985. Aseptic micropropagation of Rhododendron P.J.M hybrids. J. Hort. Sci. 60:269-274.
Evans, D.A. 1988. Applications of somaclonal variation, p. 203-233. In: A. Mizrahi (ed.). Biotechnology in agriculture. Allan R. Liss, New York.

Gaspar, T., D. Hagege, C. Kevers, C. Penel, M. Crevecoeur, I. Engelmann, H. Greppin, an J-M. Foidart. 1991. When plant teratomas turn into cancers in the absence of pathogens. Physiol. Plant. 83:696-701.

Griesbach, R.J., P. Semeniuk, M. Roh, and R.H. Lawson. 1988. Tissue culture in the improvement of Eustoma. HortScience 23:791.

Hartmann, H.T. and D.E. Kester. 1983. Plant propagation. Prentice-Hall, Englewood Cliffs, N.J.

Jackson, J.A. and R.F. Lyndon. 1990. Habituation: Cultural curiosity or developmental determinant? Physiol. Plant. 79:579-583.

James, S. 1984. Lignotubers and burls-Their structure, function and ecological significance in Mediterranean ecosystems. Bot. Rev. 50:225-266.

Karp, A. 1989. Can genetic instability be controlled in plant tissue cultures? Nwsl. Intl. Assn. Plant Tissue Cult. 58:2-11.

Keith, V.M. and M.H. Brand. 1995. Influence of culture age, cytokinin level, and retipping on growth and incidence of brooming in micropropagated rhododendrons. J. Environ. Hort. 13:72-77.

Kerbauy, G.B., J.A. Peters, and K.G. Hell. 1986. Cytokinin autotrophy and differentiation in tissue cultures of haploid Nicotiana tobacum L. Plant Sci. 45:125-132.

LaMondia, J.L., T.M. Rathier, V.L. Smith, T.M. Likens, and M.H. Brand. 1992. Tissue proliferation/crown gall in rhododendron. Yankee Nursery Quarterly 2:1-3.

Linderman, R.G. 1993. Tissue proliferation. Amer. Nurseryman 178:56-67.

Lloyd, G. and B. McCown. 1980. Commercially-feasible micropropagation of mountain laurel, Kalmia latifolia, by use of shoot tip culture. Combined Proc. Intl. Plant Prop. Soc. $30: 421-426$.

Marcotrigiano, M. 1990. Genetic mosaics and chimeras: Implications in biotechnology, p. 85-111. In: Y.P.S. Bajaj (ed.). Biotechnology in agriculture and forestry. vol. II. Springer-Verlag, Berlin.

Marks, T.R. 1991a. Rhododendron cuttings. I. Improved rooting following "rejuvenation" in vitro. J. Hort. Sci. 66:102-111.

Marks, T.R. 1991b. Rhododendron cuttings. II. Factors affecting rooting following micropropagation. J. Hort. Sci. 66:113-118.

McCown, B.H. and G.B. Lloyd. 1983. A survey of the response of Rhododendron to in vitro culture. Plant Cell Tissue Organ Cult. 2:77-85.

Meins, F., Jr. 1989. Habituation: Heritable variation in the requirement of cultured plant cells for hormones. Annu. Rev. Genet. 23:395-408.

Meins, F., Jr., and A. Binns. 1977. Epigenetic variation of cultured somatic cells: Evidence for gradual changes in requirement for factors promoting cell division. Proc. Natl. Acad. Sci. 74:2928-2932.

Pierik, R.L. 1989. In vitro culture of higher plants. Martinus Nijhoff, Dordrecht.

Poethig, R.S. 1990. Phase change and the regulation of shoot morphogenesis in plants. Science 250:923-930.

SAS Institute. 1990. SAS/STAT user's guide. version 6, 4th ed. SAS Inst., Cary, N.C.

Shoemaker, R.C., K.A. Amberger, R.G. Palmer, L. Oglesby, and J.P. Ranch. 1991. Effects of 2,4-dichlorophenoxyacetic acid concentration on somatic embryogenesis and heritable variation in soybean (Glycine max L. Mer. R.). In Vitro Cell Dev. Bio. 27:84 88.

Skirvin, R.M. 1978. Natural and induced variation in tissue culture. Euphytica 27:241266.

Skirvin, R.M., K.D. McPheeters, and M. Norton. 1994. Sources and frequency of somaclonal variation. HortScience 29:1232-1237.

Syono, K. 1979. Correlation between induction of auxin-non-requiring tobacco calluses and increase in inhibitor(s) of IAA-destruction activity. Plant Cell Physiol. 20:29-42.

Webster, C.A. and O.P. Jones. 1989. Micropropagation of the apple rootstock M-9: Effect of sustained subculture on apparent rejuvenation in vitro. J. Hort. Sci. 64:421428 .

Table 4. The development of adventitious meristem masses and habituated morphology on Rhododendron 'Montego' shoot bases in response to $2 \mathrm{iP}$ concentration.

\begin{tabular}{|c|c|c|c|c|c|}
\hline \multirow[b]{3}{*}{$\begin{array}{l}2 \mathrm{iP} \text { concn } \\
(\mu \mathrm{M})\end{array}$} & \multicolumn{4}{|c|}{ Adventitious meristem production } & \multirow{3}{*}{$\begin{array}{c}\text { Cultures with } \\
\text { tumorization } \\
\text { and habituation } \\
(\%)\end{array}$} \\
\hline & \multicolumn{2}{|c|}{ 1st subculture } & \multicolumn{2}{|c|}{ 2nd subculture } & \\
\hline & $\begin{array}{c}\text { Cultures } \\
(\%)^{2}\end{array}$ & Rating $^{y}$ & $\begin{array}{c}\text { Cultures } \\
(\%)\end{array}$ & Rating & \\
\hline 10 & $73 b^{x}$ & $1.2 \mathrm{~b}$ & $83 \mathrm{~b}$ & $1.5 \mathrm{~b}$ & $10 \mathrm{~b}$ \\
\hline 50 & 95 a & $2.6 \mathrm{a}$ & $100 \mathrm{a}$ & $3.8 \mathrm{a}$ & $50 \mathrm{a}$ \\
\hline
\end{tabular}

${ }^{\mathrm{z}} \mathrm{A}$ total of 40 cultures per $2 \mathrm{iP}$ concentration was evaluated.

${ }^{y}$ Adventitious meristem mass diameter $(\mathrm{mm})$ was rated according to the following categories: $0=$ none; $1=0-2 ; 2=2.1-4 ; 3=4.1-8 ; 4=8.1-12 ; 5=\geq 12.1$.

${ }^{x}$ Mean separation within columns by Tukey's HSD test at $P \leq 0.05$. 